\title{
The Effect of the Dimensions of Transformational Leadership on the Teachers' Performance in the Yemeni Public Schools
}

\author{
Mohammed Alzoraiki \\ Othman bin Ab. Rahman \\ Mahazan Abdul Mutalib
}

Faculty of Leadership and Management, Universiti Sains Islam Malaysia

Doi:10.19044/esj.2018.v14n25p322 URL:http://dx.doi.org/10.19044/esj.2018.v14n25p322

\begin{abstract}
The aim of this study is to determine the dimensions of transformational leadership that influence schools to achieve productivity growth and improve the performance of teaching as well as gaining access to new high-quality education. Although schools have been competing to gain high-quality education, empirical evidence shown that many educational processes with regards to teaching performance were not successful particularly in Yemen. Consequently, the study is often concentrated on identifying the paths to enhance teaching performances. The most important factor to successfully increase high-quality education is providing appropriate transformational leadership during the process of reform, particularly in the important period of the teaching process. In order to accept changes and focus on attaining ambitious goals, it is necessary for leaders of transformational school to provide rewards and support the teachers. This paper aimed to investigate the influence of various dimensions of transformational leadership on performance of teachers in Yemeni public schools. In order to guarantee the sample's representativeness, the questionnaires have been distributed to Yemeni public schools in Sana'a, Republic of Yemen. A total of 374 respondents were selected which include staff and teachers as the sample. The instrument used was a Likert 5-point scale from the questionnaire which were examined using smartpls3. The results revealed that all the dimensions of transformational leadership have a positive influence on the teachers' performance.
\end{abstract}

Keywords: Transformational Leadership, Teachers' Performance, Yemen.

\section{Introduction}

A school's success depends considerably on the quality of its 
educational leadership (Ibrahim et al., 2014; Aydin, S., \& Uysal, 2013; Ibrahim \& Wahab, 2012; Kurland et al., 2010). Leadership is a grouping of capability and knowledge to bring a group of people to accomplish a common goal and assemble them to work towards this goal (Zembat et al., 2010). Surely, the success of the education system in any country is due to the hard work and commitment of its teachers and principals in the schools.

According to Rennie (2013), employees are the mainstay of each institution and the success of its formation depends on the performance of its staff. In the educational environment, improvement of the organizational performance should be headed by workers who are qualified and appropriate. The performance of staff is one of the important measures highlighted by senior management and the staff should be interested to improve their own performance and realize the frequently rapid progress of the knowledge and skills needed in unstable environments (Shariff, Zainal \& Hashim, 2010). Leadership in the field of education has been studied widely by many researchers (Northouse, 2013; Yukl, 2010; Bass \& Riggio, 2006; Barnett el at., 2001). Most practical studies on leadership have examined trends and examples. The two forms of leadership style and are most notably compared have been established between transformational and transactional leadership which are suggested through the full-scale model of leadership (Eyal \& Roth, 2011).

Therefore, employees' development is an essential element in educational management because they are the nation's most valuable resource. (Prasertcharoensuk \& Tang, 2017). According to Wahab et al., (2014). It is observed that numerous teachers who do not possess job satisfaction have made them less committed to the task given. To handle this issue, managers must provide themselves with the knowledge of organizational leadership. Thus, practicing a leadership approach that can strengthen the relation between colleagues and co-workers can create a suitable working environment and tremendous job satisfaction for them. Hence, transformational leadership is mostly related to effective leadership style where the focus is on the ability to improve subordinates' knowledge and motivation as well as resulting in organizational excellence (Leithwood \& Sun, 2012; Amin, et al, 2013; Aydin et al., 2013; Selamat, et al., 2013).

Transformational leaders can be known as leaders who positively perceived future scenarios for organizations. (Ahmetasevic et al., 2018). Therefore, transformational principals have excellent ability to influence organizational teacher's commitment by promoting values that are relevant to achieve the targeted goal. Some of the ways is to emphasize the relationship between teacher's efforts and purpose achievement and building a greater level of individual commitment for both teachers and 
principals of the schools. This can lead to a higher performance and thus increase the quality of education. Moreover, transformational leadership in educational environment works by encouraging the school staff to generate a feeling of efficiency that leads to an enhanced performance (Alsaeedi, \& Male, 2013).

\section{Statement of Problem}

Yemen Ministry of Education in 2013 declared that the public education in Yemen suffered many problems including low performance in the quality of education. This is due to the low performance of teachers and school principals. According to UN Special Envoy for Global Education (2013), the issue regarding the lack of commitment among teachers and supervisory staff has risen from 2010 to 2011 due to industrial activities and weak official monitoring at both centralized and decentralized levels. According to the World Bank (2013), a study indicated that the average rate of teachers' commitment is 19 percent and their time to deliver the lesson is reduced which causes the students to learn only a fifth what they officially supposed to be learning. Thus, this decreases the performance and efficiency of the teachers. All those factors lead to poor performance of teachers and therefore, poor quality of education.

\section{Objective}

The objective of this study is to examine the effects of transformational leadership (dimensions) on teacher's performance in Yemeni public schools.

Transformational Leadership is one of the significant leadership models and it is largely important in the field of educational administration (Hallinger, 2003; Bush, 2014). According to Okoth, (2018), educational leadership duties include setting educational standards, giving the motivation to learn, and providing incentives for teachers. Principals encourage teachers to understand the effectiveness, sense of society, attention, professional development and improvement of education. Furthermore, transformational leadership in educational context works through inspiring the school staff to build a feeling of success that leads to enhance student outcomes (Alsaeedi \& Male, 2013). Meanwhile, the application of transformational leadership among school leaders is very important to enhance the performance of teachers through knowledge development. Transformational leadership can promote the changes required to accomplish particular goals. It includes the following dimensions: Idealized Influence, Inspirational Motivation, Intellectual Stimulation, and Individualized Consideration. These are further clarified 
based on figure 1.

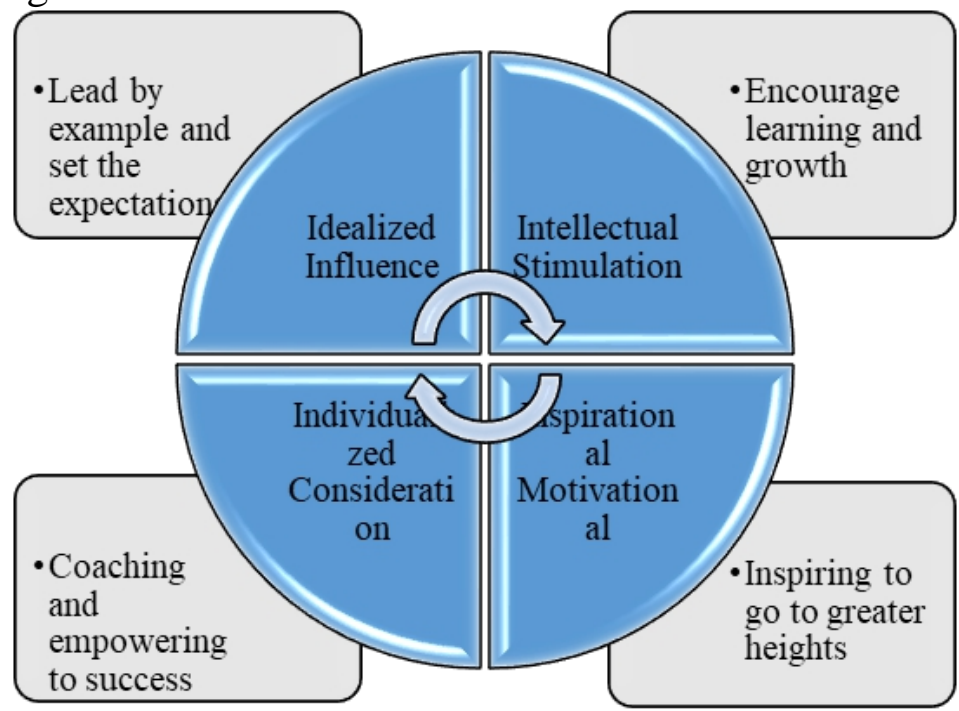

Figure 1 Dimensions of Transformational Leadership Model

\section{Idealized Influence}

This dimension is also named the Behavioral Charisma (Avolio, \& Yammarino 2013). The leader in this context is the role model who provides a sense of purpose by instilling a common vision and clear objectives. Besides being respected as the main operator of great performance and spirit, he or she is also seen as an idealized leader who steps ahead of his or her followers as well as understanding the central force of the organization to move forward with (Avolio, 2011). Additionally, through the use of vision, transformational leaders with this factor instill a sense of faith for a better future (Berson, et al., 2001).

\section{Inspirational Motivation}

The leader with the Inspirational Motivation dimension influences his or her followers by continuously motivating them to go above and beyond as well as using extra effort and doing something greater than expected. The leader also provides motivating goals by assigning tasks that are meaningful and challenging (Avolio, 2011).

\section{Intellectual Stimulation}

This dimension of refers to leaders that inspire and stimulate their followers by encouraging creativity and innovation. Besides stimulating followers to think in new ways, a leader with intellectual stimulation factor emphasizes problem-solving and the use of reasoning before implementing a solution (Lowe et al., 1996). Intellectual stimulation that is used for 
producing new ideas and solving problems will conjointly influence organizational performance through innovation (García-Morales et al., 2012).

\section{Individualized Consideration}

Individualized consideration focuses towards the leader's procedure on how he monitors his subordinates in achieving their targeted level of potential. In this context, the leader plays his or her role as a coach and advisor apart from also offering opportunities that are capable of challenging the workers' development and growth (Bass, 1999). Yukl (2006) explained that the leaders developed individual behaviors through support and encouragement as well as provide training for his followers.

Previous research has proved that there is a statistically positive association between transformational leadership and subordinate's performance (Masi \& Cook, 2000; Dvir et al., 2002; Bass et al., 2003). Further, it has also been confirmed that leaders who demonstrate transformational leadership tend to improve performances more efficiently and these outcomes were confirmed across certain levels as well as in public circumstances (Bakar \& Mahmood, 2013a). Additionally, it has been revealed that transformational leadership is common in the public education sector as it represents the overall performance (Tucker, 1991; Kirby, King \& Paradise, 1992). Based on these arguments, the following hypothesis is postulated:

* H1: Transformational leadership has a significant impact on teachers' performance in Yemeni public schools.

Consequently, the sub-hypothesis will be as following:

* H1.1 Idealized Influence has a significant impact on teachers' performance in Yemeni public schools.

* H1.2 Inspirational Motivation Influence has a significant impact on teachers' performance in Yemeni public schools

* H1.3 Intellectual Stimulation has a significant impact on teachers' performance in Yemeni public schools.

* H1.4 Individualized consideration Stimulation has a significant impact on teachers' performance in Yemeni public schools.

The study on the relationship between transformational leadership and performance has attracted the interest of numerous scholars (Menges et al., 2011; Carter et al., 2012; Braun, et al., 2013). Nevertheless, there is no study which examines the relationship between transformational leadership, teacher's commitment, and teacher's performance, particularly in Yemen. 


\section{Transformational leadership \\ Idealized Influence \\ Inspirational Motivation \\ Intellectual Stimulation}

Figure 2 Conceptual framework

\section{Methodology}

A questionnaire was utilized in this study which has benefits in terms of obtaining data more efficiently over time and reducing energy and expenditures (Sekaran, 2006). The population of this study consisted of 13198 public school teachers in Yemen whereas the sample size consisted of 374 teachers. The sampling technique employed in this study is stratified random sampling. This study covers 10 educational districts which includes 302 public schools in Sana'a whereby the targeted population consists of public school teachers that are currently teaching there. The data collected was analyzed using SPSS (version 25) to evaluate the effects of the dimensions of transformational leadership on teacher's performance. Multiple regression analysis was used as well as the Smart pls 03 software to test the hypothesis.

\section{Instrument}

The study employed a questionnaire developed by Alfraih, F. (2014) for measuring the style of transformational leadership. The questionnaire consists of 21 items that measure four dimensions of transformational leadership: idealized influence, inspirational motivation, intellectual stimulation, and individual consideration. Based on the fivepoint Likert scale which ranges from 1 (strongly agree) to 5 (strongly disagree), the respondents were required to answer their transformational leadership styles. To measure the teachers' performance in Yemeni public schools, The Teachers' performance (TP) scale based on Alfahadi, et al., (2016) was approved and utilized for this research. The questionnaire consists of 24 items and is based on the range given in the five-point Likert: 1 (strongly agree) to 5 (strongly disagree).

\section{Reliability and Validity}

Before the relations between transformational leadership and teacher's performance were measured and determined, the instrument was studied and evaluated in order to measure its reliability and validity. 
Cronbach's alpha coefficient was carried out and test results ranging from 0.855 to 0.919 were obtained, which exceeds the recommended minimum level of 0.7 (Nunnally, 1978). A low alpha value indicates a weak correlation between items which suggests that some of them should be amended or discarded. Nunnally $(1978 ; 1988)$ stated that a newly developed instrument is acceptable on the basis that the alpha value is 0.60 , by which 0.70 must be the threshold. Hence, this suggests that there is a relatively high degree of reliability for the instrument (See Table 1 below).

Table 1: Reliability scores

\begin{tabular}{llll}
\hline & Cronbach's Alpha & Composite Reliability & (AVE) \\
\hline IIN & 0.871 & 0.903 & 0.609 \\
IM & 0.884 & 0.915 & 0.683 \\
IS & 0.862 & 0.901 & 0.645 \\
IC & 0.855 & 0.896 & 0.634 \\
TP & 0.952 & 0.955 & 0.507 \\
\hline
\end{tabular}

The variables were validated in this study by factor analysis. Prior to the analysis, the appropriateness of the data was evaluated using two tests, Kaiser-Meyer-Olkin measure of sampling adequacy (KMO) and Bartlett's Test of Sphericity. While the KMO must be more than 0.50 or equal to 0.822 , it is necessary for the Bartlett's Test of Sphericity to be significant. For factor analysis, principle component analysis and Varimax rotation were obtained. It was proposed that the items with factor loadings less than 0.40 must be removed (Hair et al., 2006). Table 2 illustrated that the KMO value for transformational leadership was 0.953 while the KMO for teacher's performance was 0.848 and the Bartlett's Test of Sphericity was significant. Factor loading was based on 21 items that represented transformational leadership and 24 items that represented teacher's performance.

\section{Hypotheses Testing}

Structural Equation Modeling analysis (smartpls3) was employed to investigate $\mathrm{H} 1$ - the relationship between transformational leadership and teacher's performance. Structural Equation Modeling Smart pls3 was employed because other than predicting the effect of independent variables (transformational leadership dimensions) on the dependent variable (teachers' performance), it also investigates the unique strength and direction of the individual contribution of independent variables on the dependent variable at the same time. Results from the analysis presented in Table 2 showed that the main hypothesis was accepted due to the t statistics $=9.476$ which is greater than the table $=1.96$. This means that the transformational leadership has a positive significant effect on the teachers' 
performance in Yemeni public schools.

Table 2. Path Coefficients (MEAN, STDEV, and T-Value)

\begin{tabular}{|c|c|c|c|c|c|}
\hline & $\begin{array}{l}\text { Original } \\
\text { Sample }(\mathrm{O})\end{array}$ & $\begin{array}{l}\text { Sample } \\
\text { Mean (M) }\end{array}$ & $\begin{array}{l}\text { Standard } \\
\text { Deviation } \\
\text { (STDEV) }\end{array}$ & $\begin{array}{l}\text { T } \quad \text { Statistics } \\
(|\mathrm{O} / \mathrm{STDEV}|)\end{array}$ & P Values \\
\hline TFL -> IC & 0.865 & 0.863 & 0.02 & 42.988 & 0 \\
\hline TFL -> IIN & 0.87 & 0.868 & 0.02 & 43.074 & 0 \\
\hline TFL -> IM & 0.902 & 0.901 & 0.014 & 63.475 & 0 \\
\hline TFL -> IS & 0.938 & 0.938 & 0.009 & 103.567 & 0 \\
\hline TFL -> TP & 0.48 & 0.499 & 0.051 & 9.476 & 0 \\
\hline
\end{tabular}

Figure 3 shows that dimensions of transformational leadership has a significant relationship with teacher's performance. Consequently, $\mathrm{H} 1$ is accepted. The H1 result is in line with the previous studies by which transformational leadership is significantly related to performance (Judge \& Piccolo, 2004; Bass, Avolio, et al., 2003). These results also confirmed earlier studies that associate transformational leadership with higher performance (Masi \& Cooke, 2000). Block (2003) eloquently stated that transformational leadership is powerful and it results in greater performance and productivity.

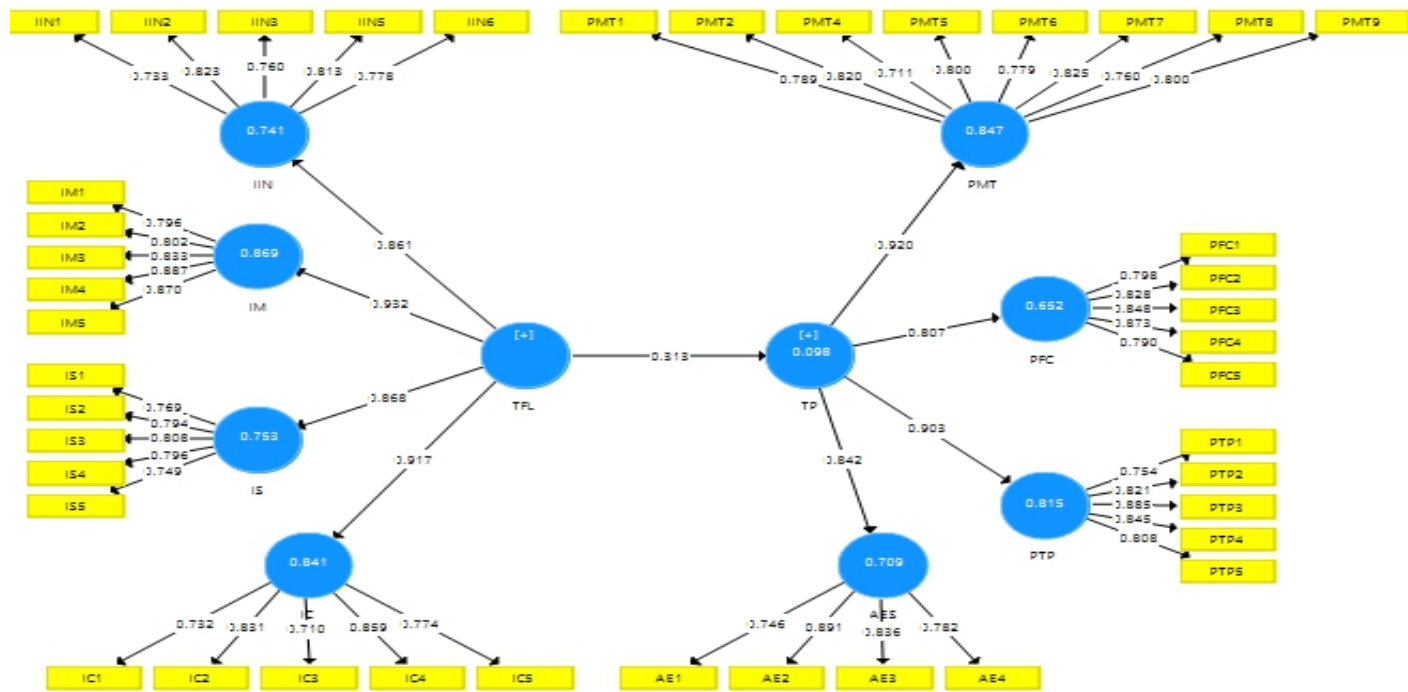

Figure 3 PLS Path coefficient and R square

\section{Discussions and Conclusion}

The major goal of this study is to investigate the effects of transformational leadership dimensions on Yemeni public-school teachers' performance. Based on the results, it has been revealed that transformational leadership has a statistically significant effect on the teachers' performance. Consequently, this implies that a high level of 
transformational leadership would result in a high level of performance for the teachers in Yemeni public schools. This finding is similar with past studies that strongly support the influence of transformational leadership to increase the performance of several instructional establishments (Bass, 1998; Bass et al., 2003; Yukl, 2010; Northouse, 2010; Wang et al., 2011; Aziz et al., 2013) as well as the higher education sector (Lo et al., 2009; Hashim, 2010; Sadeghi \& Zaidatol, 2013, Sitthisomjin, J.et al., 2018). Consequently, public-school leaders should attempt to select and encourage transformational leadership qualities among Yemeni teachers to increase their performance. Their leadership aspects must be considered when selecting the education managerial position. Additionally, current school leaders must reconsider their style of selection in leadership because it has a vital impact on performance. Due to the rapid development of education throughout the world, it is essential that Yemeni public schools continue to progress, so students can learn quickly and effectively. This is also to ensure their flexibility and sustainability for future success. Transformational leaders can observe their schools and constantly reinvent necessary changes when needed for further improvement. The leaders must possess the ability to share a vision about future possibilities which inspires their subordinates to make the group's needs their priority instead of their own personal interests (Early \& Davenport, 2010; O’Reilly et al., 2010). Hence, in today's environment of public school education, transformational leadership is indeed the desired quality that leaders should have. This work is conducted based on the knowledge of leadership attributes and behaviors in public-school education. However, it suffers from some limitations that should be taken into consideration for future studies. In this study, only one research methodology was used thus, it is suggested that the triangulation approach should be used in future research.

\section{References:}

1. Ahmetasevic, J., \& Obralic, M. (2018). Influence of Transformational Leadership on Novelty of Product Ideas: Validation of Theoretical Model. European Scientific Journal, ESJ, 14(7).

2. Alsaeedi, F., \& Male, T. (2013) 'Kuwait Transformational Leadership and Globalization: Attitudes of School Principals in Kuwait', Educational Management Administration and Leadership, 41(5), 640-657.

3. Amin, M., Shah, S., \& Tatlah, I. A. (2013). Impact of principals, directors' leadership styles on job satisfaction of the faculty members: Perceptions of the faculty members in a public university of Punjab, Pakistan. Journal of Research, 7(2), 97-112. 
4. Avolio, B. J. (Ed.). (2011). Full range leadership development. Sage.

5. Avolio, B.J., \& Yammarino, F. J. (2013). Transformational and charismatic leadership: The road ahead 10th anniversary edition, Emerald Group Publishing Limited.

6. Aydin, A., Savier, Y., \& Uysal, S. (2013). The effect of school Principals' leadership styles on teachers' organizational commitment and job satisfaction. Educational Sciences: Theory and Practice, 13(2), 805-811.

7. Aziz R., M.H., Abdullah, A., Tajudin \& Mahmood. R. (2013). The effect of leadership styles on the business performance of SMEs in Malaysia, International Journal of Economics and Management Studies, 2(2), 45-52.

8. Bakar, M. S., \& Mahmood, R. (2014). Linking transformational leadership and corporate entrepreneurship to performance in the public higher education institutions in Malaysia. Advances in Management and Applied Economics, 4(3), 109.

9. Barnett, K., McCormick, J., \& Conners, R. (2001). Transformational leadership in schools-panacea, placebo or problem. Journal of Educational Administration, 39(1), 24-46.

10. Bass, B. M. (1998). The ethics of transformational leadership. Ethics, the heart of leadership, 169-192.

11. Bass, B. M., \& Riggio, R. E. (2006). Transformational leadership. Psychology Press.

12. Bass, B. M., Avolio, B. J., Jung, D. I., \& Berson, Y. (2003). Predicting unit performance by assessing transformational and transactional leadership. Journal of applied psychology, 88(2), 207.

13. Bass. (1999). Two decades of research and development in transformational leadership. European journal of work and organizational psychology, 8(1).

14. Berson, Y., Shamir, B., Avolio, B. J., \& Popper, M. (2001) 'The relationship between vision strength, leadership style, and context', The Leadership Quarterly, vol. 12, no. 1, pp. 53-73.

15. Block, L., (2003). The leadership-culture connection: an exploratory investigation. Leadership \& Organization Development Journal, 24(6), 318-334.

16. Braun, S., Peus, C., Weisweiler, S., \& Frey, D. (2013). Transformational leadership, job satisfaction, and team performance: A multilevel mediation model of trust. The Leadership Quarterly, 24(1), 270-283. Doi.org/10.1016/j. leaqua.2012.11.006

17. Bush, T. (2014). Instructional and transformational leadership: 
Alternative and complementary models?" Educational Management Administration and Leadership, Vol. 42 No. 4, pp. 443-444.

18. Carter, M., Armenakis, A., Field, H., \& Mossholder, K. (2012). Transformational leadership, relationship quality, and employee performance during continuous incremental organizational change. Journal of Organizational Behavior, 34(7), 942-958. doi: 10.1002/job.1824

19. Dvir, T., Eden, D., Avolio, B. J., \& Shamir, B. (2002). Impact of transformational leadership on follower development and performance: A field experiment. Academy of management journal, 45(4), 735-744.

20. Early, J., \& Davenport J. B., (2010). Desired qualities of leaders within today's accounting firm, The CPA Journal, 80(3), 59-62.

21. Eyal, O., \& Roth, G. (2011). Principals' leadership and teachers' motivation: Self-determination theory analysis. Journal of Educational Administration, 49(3), 256-275.

22. García-Morales, V. J., Jiménez-Barrionuevo, M. M., \& GutiérrezGutiérrez, L. (2012). Transformational leadership influence on organizational performance through organizational learning and innovation. Journal of business research, 65(7), 1040-1050.

23. Hallinger, P. (2003). Leading educational change: Reflections on the practice of instructional and transformational leadership. Cambridge Journal of Education, Vol. 33 No. 3, pp. 329-352.

24. Hashim R.A., (2010). The mediating effect of job satisfaction on the relationship between perceived leadership styles and commitment to service quality among academic staff in selected Malaysian universities, Unpublished DBA thesis, Universiti Utara Malaysia,

25. Ibrahim, M. S., Ghavifekr, S., Ling, S., Siraj, S., \& Azeez, M. I. K. (2014). Can transformational leadership influence on teachers' commitment towards organizational, teaching profesion and students learning? A quantitative analysis. Asia Pacific Educ. Rev., 15, 177-190. http://dx.doi.org/10.1007/s12564-013-9308-3

26. Judge, T. A., \& Piccolo, R. F. (2004). Transformational and transactional leadership: a meta-analytic test of their relative validity. Journal of applied psychology, 89(5), 755.

27. Kurland, H., Peretz H., \& Hertz-Lazarowitz, R. (2010). Leadership style and organizational learning: The mediate effect of school vision. Journal of Educational Administration 48: 7-30.

28. Leithwood, K. A., \& Sun, J. (2012). The nature and effects of Transformational school leadership a meta-analytic review of unpublished research. Educational Administration Quarterly, 
48(3), 387-423. http://dx.doi.org/10.1177/0013161X11436268.

29. Lo, M. C., Ramayah, T., \& de Run, E. E. C. (2009, January). Testing the multi-dimensional nature of" new leadership" in a non-western context: The case of Malaysia. In Allied Academies International Conference. Academy of Educational Leadership. Proceedings (Vol. 14, No. 1, p. 25). Jordan Whitney Enterprises, Inc.

30. Lowe, K. B., Kroeck, K. G., \& Sivasubramaniam, N. (1996). Effectiveness correlates of transformational and transactional leadership: A meta-analytic review. Leadership Quarterly, 7, 385425.

31. M. o. E. (2013). Educational Indicators in Republic of Yemen 2012/2013.

32. Masi, R. J., \& Cooke, R. A. (2000). Effects of transformational leadership on subordinate motivation, empowering norms, and organizational productivity. The International Journal of Organizational Analysis, 8(1), 16-47.

33. Menges, J., Walter, F., Vogel, B., \& Bruch, H. (2011). Transformational leadership climate: Performance linkages, mechanisms, and boundary conditions at the organizational level. The Leadership Quarterly, 22(5), 893- 909. doi: 10.1016/j.leaqua.2011.07.010

34. Northouse P.G., (2010). Leadership: theory and practice, Thousand Oaks, Sage,

35. Northouse, P. G. (2013). Leadership: Theories and practice (6th Ed.). Thousand Oaks, CA: SAGE.

36. Nunnally, J. C. (1978). Psychometric theory (2nd Ed.). New York, NY: McGraw-Hill.

37. O’Reilly C. A., D. F., Caldwell, J.A., Chatman, M. Lapiz \& Self, W. (2010). How leadership matters: the effects of leaders' alignment on strategy implementation, Leadership Quality, 21(1), 104-113.

38. Okoth, U. A. (2018). Transformational Leadership Practices in Curriculum Implementation (Environmental Education) in Secondary Schools in Siaya County, Kenya. European Scientific Journal, ESJ, 14(10).

39. Prasertcharoensuk, T., \& Tang, K. N. (2017). The effect of strategic leadership factors of administrators on school effectiveness under the Office of Maha Sarakham Primary Educational Service Area 3. Kasetsart Journal of Social Sciences. 38(3), 316-323

40. Sadeghi, A., \& Pihie, Z. A. L. (2013). The role of transformational leadership style in enhancing lecturers' job satisfaction. International Journal of Business and Social Science, 4(8). 264- 
271.

41. Sekaran, U. (2006). Research methods for business: A skill building approach (4th ed.). Danvers, MA: John Wiley \& Sons Inc.

42. Selamat, N., Nordin, N., \& Adnan, A. A. (2013). Rekindle teachers' organizational commitment: The effect of Transformational leadership behavior. Procedia Ssocial and behavioral sciences, 90, 566-574. http://dx.doi.org/10.1016/j.sbspro.2013.07.127

43. Shariff, F. M., Zainal, A., \& Hashim, R. (2010). The moderating effect of change behavior on the relationship between employee characteristics and employee job performance: a study on Malaysian hospitality industry. In Proceedings of the regional conference on statistical sciences (pp. 322-334).

44. Sitthisomjin, J., Somprach, K., \& Phuseeorn, S. (2018). The effects of innovation management on school performance of secondary schools in Thailand. Kasetsart Journal of Social Sciences.

45. Wahab, J. A., Fuad, C. F. M., Ismail, H., \& Majid, S. (2014). Headmasters' Transformational Leadership and Their Relationship with Teachers' Job Satisfaction and Teachers' Commitments. International Education Studies, 7(13), 40-48.

46. Wang, G., Oh, I. S., Courtrigh, I. H., \& Colbert, A. E. (2011). Performance across criteria and levels: a meta-analytic review of 25 years of research, Group and Organization Management, 36(2), 223-270.

47. World Bank. (2013c). Yemen - Basic Education Development Program Project. Washington DC; World Bank. Retrieved from http://documents.worldbank.org/curated/en/2013/06/18063624/ye men-basic-education-development-program-project

48. Yukl, G. (2010). Leadership in organizations (7th Ed.). Upper Saddle River, NJ: Prentice Hall.

49. Yukl. (2006). Leadership in organizations. Upper Saddle River: Pearson Prentice Hall.

50. Zembat. R., Kocyigit, S., Tugluk, M. N. \& Dogan, H. (2010). The relationship between the effectiveness of preschools and leadership styles of school managers. Procedia Social and Behavioral Sciences 2: 2269-2276. 